\title{
Dominance of Technical Facilities Available in Individuals based Bank than Compared to Corporate based Banks
}

\author{
S. Janifarvinnarasi, N. Mathankumar, M. Sankar
}

\begin{abstract}
The Banking business like numerous other money related assistance enterprises is confronting a quickly evolving business sector, new advancements, financial vulnerabilities, wild challenge and all the more requesting clients and the changing atmosphere has displayed a remarkable arrangement of difficulties. Banking is a client situated administrations industry, in this manner, the client is the concentration and client support is the separating factors. In the setting of every one of these improvements the agent makes an endeavor to clarify the Customer Service fulfillment in Indian Banking Sector. In this examination paper, the fundamental conflict is to feature the consumer loyalty gave by chosen Banks Kotak Mahindra Bank and IDBI Bank.
\end{abstract}

Keywords: Customer satisfaction, banking services.

\section{INTRODUCTION}

The present alter in the helpful course of Banks, the inspiration driving Banking is rethought. Directly, the Financial Institutions are endeavoring to give all of the organizations at the customer's doorstep. The customer has become the purpose of assembly either to make or keep up sufficiency in the business. Every dedication with the customer is an opportunity to either make or pulverize a customer's trust in the Bank. The wants for the customers have furthermore extended various folds. Genuine competition among the Banks has renamed the thought of the entire Banking system. The Banks are looking for new ways not solely to attract yet notwithstanding hold the customers and increment high ground over their adversaries. The Banks like distinctive business affiliations are passing on creative

arrangements frameworks and pushed exhibiting instruments to get incredibleness. The essential driver of this change is changing customer needs and wants. Customers in urban India never again need to hold up in long queues and experience hours in Banking trades. This change in customer attitude has gone inseparable with the progression of ATMs, phone and net Banking nearby openness of organization legitimately at the customer's doorstep. With the ascent of general Banking, Banks plan to give all Banking thing and

Revised Manuscript Received on December 30, 2019.

S.Janifarvinnarasi, Assistant Professor, Department Of Science and Humanities,Bharath Institution Of Higher Education And Research TamilNadu,India,Email: mjjaa24@gmail.com

N.Mathankumar, Assistant Professor, Department Of Science and Humanities,Bharath Institution Of Higher Education And Research TamilNadu,India,Email: ma.aswinkumar18@gmail.com

M.Sankar Assistant Professor, Department Of Science and Humanities,Bharath Institution Of Higher Education And Research TamilNadu,India,Email sankar06.phd@gmail.com organization offering shy of what one housetop and their endeavor is to be customer driven. With the improvement of money related changes in world when in doubt and in India explicitly, private Banks have come up in a significant way with prime emphasis on particular and customer focused issues. In this assessment, the crucial clash is to include the customer dependability for the organizations gave by the Banks - IDBI Bank and Kotak Mahindra Bank Comparative Analysis[1]-[4]

\section{REVIEW OF LITERATURE}

Tse and Wilton (1988) characterized Customer fulfillment is, "the buyer's reaction to the assessment of the apparent disparity between earlier desires and the real execution of the item seen after its utilization. Jamal, A., \&Naser, K. (2002) have investigated the effect of administration quality measurements and client skill on fulfillment in their examination. They talked with test of 167 respondents as a piece of their examination. Their discoveries showed that both center and social elements of administration quality gave off an impression of being connected to consumer loyalty. They additionally found that mastery is contrarily identified with fulfillment. The paper examines suggestions for Bank chiefs. [5]-[10]

Zani, S., \&Berzieri, L. (2008) managed the issue of estimating Customer Satisfaction utilizing a few ordinal factors with various number of classes. They applied some multivariate strategies to the consequences of a study on the clients of the Contact Center of the Municipality of Parma, so as to quantify the nature of the administration and the resident fulfillment. Further they utilized various methodologies for the evaluation of ordinal reactions in thought and examination.

Kumar, N., \&Gangal, V. K. (2011) have found in their investigation that

- The clients feel fulfill with Bank staff and furthermore lauded the endeavors of Bank staff.

- The Bank is neglected to keep up the protection of exchanges which is most extreme necessity of Bank.

- Lay out, neatness and Security and Safety of the branch are great and palatable

- Customers are prepared to prescribe this Bank to a companions or family members and stay a client of this Bank in future in as well. 
Over full scale of 31 parameters, Bank has neglected to fulfill clients at 15 parameters. Be that as it may, tragically these incorporate the most significant parameters, for example, cost of administrations, protection oftransactions, reaction time. [11]-[14]

Mistry, S. H. (2013) has found in his investigation that a client gives most elevated feebleness to dependability measurement. Further he additionally depicted that inside that unwavering quality measurement clients give more spotlight on how Banks satisfy their guarantee and how they demonstrate enthusiasm to do function. In his investigation he found that a client gives second significance to responsiveness of Bank representatives. It incorporates different criteria like, quickness in giving assistance, eagerness to help clients and so forth. Client gives third inclination to affirmation factor, it incorporate criteria like wellbeing of exchange, consistency in administration and so forth.

Felix, R. (2017) examined administration quality and consumer loyalty in BanquePopulaire du Rwanda, Kigali branches. Study uncovered that both the degree of administration quality and client..

\section{OBJECTIVES}

\section{A. Primary Objective}

To compare satisfaction level of customers towards the services provided by Kotak Mahindra

Bank and IDBI Bank

- To study major attributes of customer satisfaction of Banks.

- To study customer's perception about Kotak Mahindra Bank and IDBI Bank ltd.

- To judge the importance of attributes that influence customer's satisfaction with

- To assess level of satisfaction on services provided by Private Bank (Kotak Mahindra) and Public Sector Bank (IDBI Bank).

\section{RESULTS \& DISCUSSION}

In this examination we have utilized clear research configuration to depict the view of financial specialists towards Kotak Mahindra Bank and IDBI Bank. For this, data has been gathered from various client of Kotak Mahindra Bank and IDBI Bank. Tests for the investigation are taken simultaneously. This examination is limited to timespan beginning from January 2018 to end of February 2018, in Surat city. It comprises of an overview of 100 respondents from clients of Kotak Mahindra Bank and 100 respondents from clients of IDBI Bank, which were chosen based on non-probabilistic - advantageous testing technique. The investigation is led to quantify near degree of execution and level of fulfillment of client towards the two banks. In this investigation essential information has been gathered utilizing Questionnaire. The respondents were drawn closer actually. Auxiliary information of KotakMahindra Bank and

\section{B. Secondary Objectives:}

IDBI Bank gathered from distributed reports articles and web. The extent of the investigation is restricted to different regions of Surat city. We additionally applied T-test to look at level of fulfillment of Kotak Mahindra Bank and IDBI Bank ltd. [15]-20]

\section{Conclusion}

We have seen that IDBI Bank is entrenched while Kotak Mahindra Bank is rising bank. Client of IDBI having long haul relationship contrast with client of Kotak Mahindra Bank. Significant explanation behind determination of IDBI Bank is area related advantage where as if there should arise an occurrence of Kotak Mahindra Bank their pace of premium the explanation. Larger part client based of IDBI Bank is mid age gathering individuals with more elevated level of instruction, while if there should be an occurrence of Kotak bank youngsters having training under graduation or graduation are the client base. As far as fulfillment with respect to different perspectives like prompt reaction to issue, bank charges and so forth. Kotak Bank is altogether in front of IDBI Bank.[21]-[25]

\section{REFERENCES}

1. Vasanthi, S. \& Rabiyathul Basariya, S. 2019, "Influence of value analysis and cross training in industry", International Journal of Engineering and Advanced Technology, vol. 8, no. 6, pp. 1810-1811.

2. Velvizhi, R., Sri Gowtham, S. \& Jeya Priya, D. 2019, "Examination of early feedbacks for effective product retailing on E-commerce websites", International Journal of Engineering and Advanced Technology, vol. 8, no. 6 Special Issue 2, pp. 703-706.

3. Anuradha, C., Pothumani, S. \& Kavitha, R. 2019, "A novel method towards E-commerce", International Journal of Engineering and Advanced Technology, vol. 8, no. 6 Special Issue 2, pp. 535-538.

4. Thomas, J. \& Rabiyathul Basariya, S. 2019, "A study on the issues of financial ratio analysis", Indian Journal of Public Health Research and Development, vol. 10, no. 3, pp. 1079-1081.

5. Ramachandran, S. \& Rabiyathul Basariya, S. 2019, "Online marketing - study on customer satisfaction and relationship", Indian Journal of Public Health Research and Development, vol. 10, no. 3, pp. 1072-1078.

6. Priya, R., Vinothini, G. \& Cor Jesu, C.D. 2019, "The mentor-protégé relationship for professional growth", Journal of Advanced Research in Dynamical and Control Systems, vol. 11, no. 9 Special Issue, pp. 1110-1119.

7. Jannifer Rani, N., Bina Pani, S. \& Nimisha, N.S. 2019, "A study on money back polices available in LIC", Journal of Advanced Research in Dynamical and Control Systems, vol. 11, no. 9 Special Issue, pp. 833-839.

8. Saillaja, V., Jhansi Rani, K. \& Catherine, R. 2019, "Global marketing management planning and organization", Journal of Advanced Research in Dynamical and Control Systems, vol. 11, no. 9 Special Issue, pp. 489-493.

9. Saillaja, V., Jhansi Rani, K. \& Catherine, R. 2019, "The new phase of marketing information system", Journal of Advanced Research in Dynamical and Control Systems, vol. 11, no. 9 Special Issue, pp. 482-488.

10. Thoufiqulla \& Raju, D.V. 2019, "Perception of indian investor towards investment in mutual funds with special reference to mip funds", Journal of Advanced Research in Dynamical and Control Systems, vol. 11, no. 5, pp. 177-183.

11. Jasmine, K.R.M. \& Basariya, S.R. 2018, "A study on the customers benefits on mutual funds", International Journal of Civi Engineering and Technology, vol. 9, no. 4, pp. 45-48. 
12. Vasanthi, S. \& Basariya, S.R. 2019, "Pros and cons of on the job training versus off the job training", International Journal of Scientific and Technology Research, vol. 8, no. 10, pp. 671-674.

13. Pavithra, J. \& Ganesan, M. 2016, "A study on awareness and impact of micro-financial schemes", International Journal of Applied Business and Economic Research, vol. 14, no. 8, pp. 5449-5460.

14. Pavithra, J., Dilli Babu, P. \& Ambuli, T.V. 2014, "A study on budgetary control at Maruti Service Masters, Chennai", International Journal of Applied Business and Economic Research, vol. 12, no. 2, pp. 151-161.

15. Gunaraja, T.M. \& Venkatrama Raju, D. 2018, "Determining factors of organisational climate with reference to leadership styles", International Journal of Mechanical Engineering and Technology, vol. 9, no. 9, pp. 1327-1332.

16. Gunaraja, T.M. \& Venkatrama Raju, D. 2018, "The role of job satisfaction and training of employees in determining organisational climate of a selected industry", International Journal of Civil Engineering and Technology, vol. 9, no. 8, pp. 1266-1269.

17. Aarathy, T.S. \& Raju, D.V. 2018, "Performance appraisal and its effects on employees with respect to it sector in Chennai city", International Journal of Civil Engineering and Technology, vol. 9, no. 6, pp. 1535-1538.

18. Aarathy, T.S. \& Raju, D.V. 2018, "Employee perception towards performance appraisal system in IT sector", International Journal of Mechanical Engineering and Technology, vol. 9, no. 5, pp. 131-135.

19. Porselvi, W., Jublee, D. \& Sivanesan, G. 2018, "A study on factors influencing adoption of technology and innovation in banking industry, tamilnadu, India", International Journal of Mechanical Engineering and Technology, vol. 9, no. 5, pp. 789-800.

20. Akessa, G.M. and Dhufera, A.G., 2015. Factors That Influences Students Academic Performance: A Case of Rift Valley University, Jimma, Ethiopia. Journal of Education and Practice, 6(22), pp.55-63.

21. Miller, G. and Shih, C.C., 1999. A faculty assessment of the academic rigor of on-and off-campus courses in agriculture. Journal of Agricultural Education, 40, pp.57-65.

22. Tsinidou, M., Gerogiannis, V. and Fitsilis, P., 2010. Evaluation of the factors that determine quality in higher education: an empirical study. Quality Assurance in education, 18(3), pp.227-244.

23. Farooq, M.S., Chaudhry, A.H., Shafiq, M. and Berhanu, G., 2011. Factors affecting students' quality of academic performance: a case of secondary school level. Journal of quality and technology management, 7(2), pp.1-14.

24. Fitsilis, P., Gerogiannis, V. and Anthopoulos, L., 2014. Ontologies for software project management: a review. Journal of Software Engineering and Applications, 7(13), p.1096.

25. Adams, J.D. and Jaffe, A.B., 1996. Bounding the effects of R\&D: an investigation using matched establishment-firm data(No. w5544). National bureau of economic research.

\section{AUTHORS PROFILE}

S.Janifar vinnarasi, Assistant Professor, Department Of Science and Humanities,Bharath Institution Of Higher Education And Research TamilNadu,India,

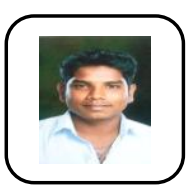

N.Mathankumar, Assistant Professor, Department Of Science and Humanities Bharath Institution Of Higher Education And Research TamilNadu,India

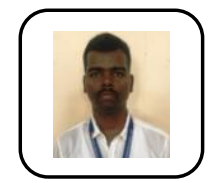

M.Sankar Assistant Professor, Department Of Science and Humanities,Bharath Institution Of Higher Education And Research TamilNadu,India 